\title{
THE REGIONAL PATTERN OF RENEWAL IN URBAN RESIDENTIAL AREAS IN GERMANY SINCE THE I970s
}

\author{
Ito Tetsuya \\ Institute of Geoscience at the University of Tsukuba, \\ Tsukuba, 305-857I, Japan \\ e-mail: tetsudeu@aol.com
}

\begin{abstract}
This study uses the case of Nuremberg to investigate the regional pattern of renewal in urban residential areas on a middle scale from the standpoint of physical and social structure in Germany since the 1970s when the supply of dwellings surpassed demand and many urban renewal projects have been carried out. I study the regional pattern of social structure, social housing units, urban renewal projects and the number of construction in the urban area. The regional pattern of renewal is divided into two types in the urban area located within a radius of $3 \mathrm{~km}$ from the city center and in the southern area.
\end{abstract}

Key words: Nuremberg, urban residential area, urban renewal, urban decline

\section{INTRODUCTION}

\section{Purpose and approaches of this study}

The purpose of this study is to investigate regional pattern of renewal in urban residential areas in Germany since the 1970s when the supply of dwellings surpassed demand. The author focuses on the renewal from the viewpoint of physical and social structure in the residential area on a middle scale though the case of Nuremberg.

From the viewpoint of methodology, this paper is composed of three parts. The first is classified into theoretical analysis, as shown in the next section. I review not only the change in housing condition after the Second World War, but also the published literatures mainly in the German speaking countries. In Part 2, I investigate regional pattern of urban residential areas from the viewpoint of social structure, based on the statistics obtained at the Department of Urban Analysis and Statistics (Amt für Stadtforschung und Statistik) in Nuremberg where the city authorities have constantly planned and complemented urban renewal projects since the 1970s. I used GIS for analyzing the statistical data. This part is to investigate the regional pattern of social structure such as spatial distribution of foreigners and old people, in order to 
make clear the difference in social environment for renewal in the urban area on a middle scale. Lastly, in the Part 3 that is based on the statistics, I investigate the regional difference in renewal that was caused by public renewal projects and construction of housing units. The analysis reveals the difference in build environment for renewal in the urban area on a middle scale.

\section{Historical overview}

The historical overview of housing condition after the Second World War is classified into three periods of time, according to the statistical analysis of data presented by the Federal Statistical Office (Statistisches Bundesamt). The first is the period up to first half of the 1970s, in which a large amount of dwellings was reconstructed in the urban central area. A great number of destroyed housing units was reconstructed under the construction incentive scheme, which started by the establishment of the First Housing Construction Act (I. Wohnungsbaugesetz) in 1950. After the mid 1950s when the urban population remarkably rose due to the economic growth, suburbanization occurred toward the urban-rural fringe.

The second period is characterized by a radical improvement in residential quality though public renewal projects undergoing clearance and reconstruction of old buildings between the mid 1960s and the late 1970s. The renewal projects emphasized the physical improvement of build environment under the concept of areal rehabilitation (Flächensanierung) in declined urban areas that were made up after the 1960s at the background of suburbanization of German from urban central area to suburbs, in contrast with increasing in foreigners around the city center. The city authorities planned public interventions for improvement in the distressed residential area, in order to reconstruct old buildings and provide new housing units. One of the most important concepts for such improvement is urban renewal or redevelopment (Stadterneuerung). After the establishment of Urban Construction Subsidy Acts (Städtebauförderungsgesetz) in 1971, local governments made many plans of renewal projects and implemented them with getting financial support by both Federal and State Governments (Heineberg, 1988, 23-4). Many old buildings were destroyed and new dwellings were constructed, but their carelessness in regard to the historical identity of residential areas and destruction of neighborhood networks were criticized (Wiessner, 1988).

The third period of time has begun in the late 1970s. Urban renewal projects have paid much more attention to the utilization of existing buildings and the spatial potential for re-use since then because of a bitterly criticism against the previous renewal projects. Main purpose of new one emphasized not only the modernization of housing, which are so-called objects redevelopment (Objektsanierung) (Heineberg, 2001, 232), but also the comprehensive improvements for residential quality, which are so-called urban renewal for maintenance (Erhaltene Stadterneuerung) or careful urban renewal (Behutsame Stadterneuerung). The financial support for modernization was legally established by the Modernization and Energy-Saving Act (Modernisierungs- und Energiesparungsgesetz) in 1978. Since the middle of the 1980s, the governments have introduced new concept of renewal projects: the ecological urban renewal (Ökologische Stadterneuerung) that emphasizes the improvements in the quality of residential environment though the planting of trees. Up to the end of 2001, the number of urban renewal 
projects reaches to about 3,500, whose budget amounts to 8,819 million Mark (Eltges und Walter, 2001).

As social concern about urban renewal increased after the 1970s, so did the number of geographical studies on urban renewal. Killisch und Moch $(1976,254-9)$ pointed out that the renewal projects caused changes in social structure in a short period of time. Müller (1985) revealed that the improvement of residential quality caused by urban renewal projects in the 1960s and 1970s led to increase in rent too. Lochner (1987) and Daase (1995) pointed out that the old inhabitants with low income had moved out and the number of people with higher socioeconomic status came into the urban renewal project's area, because of increase in the rent after renovation. The relocation and gentrification caused by renewal projects, as Carmon (1999: 145-6) points out, are criticized also in the United States and United Kingdom.

Ito (2003) revealed that the recent renewal projects classified into to Behutsame Stadterneuerung took care for the old residents, so that the number of relocation was much less than that of old projects. Hatz (2001) demonstrated that the investments from private sectors have played a vital role for the recent renewal projects. This viewpoint not only illustrates the direct effect on the project's area, but also implicates additional or indirect effect of projects, which have promoted private investments in housing renewal around the project's area for a middle or long period of time. The public projects with following private investments have a great influence on changes in demographic significance and on residential qualities on a middle scale in urban residential areas. Lichtenberger (1990) suggested that urban decay results from bad decisions of social, political and economic organizations. Her argument implies that urban renewal is complemented both by public projects and the other social and economic activities. But there are no previous studies on renewal from such viewpoint. Thus, I focus not only on the regional difference of social structure such as foreigners and old people, but also on regional pattern of residential renewal from the viewpoint of social housing units, urban renewal projects and the number of construction.

\section{REGIONAL PATTERN OF SOCIAL STRUCTURE}

\section{Changes in housing condition}

Nuremberg (Nürnberg) has 423,383 citizens in the area of 12,299.9 hectare (Amt für Stadtforschung und Statistik, 1999: 22-4) and it is classified into the largest city in the northern Bavaria known as Franconia (Franken). During the Second Word War a large part of industrial and central commercial area was destroyed by aerial bombing. After the Second World War, both industrial- and commercial facilities and housing units were rapidly reconstructed and then the population continuously increased up to half a million in 1972.

The serious shortage in dwellings was remarkably improved up to the early 1970s. According to the change in construction of housing units, the number of new housing completions up to the early 1970s is much larger than the later period of time. On average, 5,601 dwellings were annually constructed between 1950 and 1973, in contrast with only 2,208 units were annually constructed in the period 1974-2000. Many housing units were constructed in suburbs up to the early 1970 s, into which urban population of German moved from urban 
central area especially in the 1970s (Maier und Troeger-Weiß, 1990). On the other hand, foreign workers (Gastarbeiter) in-migrated to the old residential area around urban central area where there were many old deteriorating housing units. Some parts of urban area encountered social problem from the viewpoint of population structure and socioeconomic environment in the 1960s and 1970s.

After the early 1970s, Nuremberg experienced recessions two times caused by national recessions in 1973-74 and in 1981. The city economy has structurally changed during the decline of labor market. Companies in the traditional manufacturing industry sector: metal, steel and textile industry went out of the city in the 1970s. Instead of this sector, the companies of communications and production-related services such as consult, planning, and market research have played much more important role since the 1970 s, in addition to transport technology, energy technology, measurement-control engineering and consumer electronics (Amt für Stadtforschung und Statistik, 1996). As the importance of service sector increased in the urban economy, so did the role of foreign workers in simple and easy work. The ratio for foreigners continually increased after the 1970s. It grows from 7.2 percent in 1970 to 18.1 percent in 2000 .

\section{Spatial distribution of foreigners and old people}

Urban population is concentrated in the old urban area within a radius of $3 \mathrm{~km}$ from the city hall (shortly, within $3 \mathrm{~km}$ from the center) and in the large residential estate in south east part of the city. On average, the population density of 109 districts located within $3 \mathrm{~km}$ from the center reaches to 107.0 persons per hectare, which is about four times higher than the average for Nuremberg (27.3 persons per hectare).

The ratio for foreigners in the old urban area developed before the Second World War is much higher than that in suburbs outside $3 \mathrm{~km}$ from the center. It reaches to 24.9 percent in the old urban area; on the contrary, only 11.2 percent in suburbs. Foreign population is concentrated in the old urban area that was developed shortly after the period of industrialization in the 19th and the early 20th century. The area is spatially connected with the industrial and traffic area where residential environments are deteriorated by traffic noises or air pollution.

Old people more than 65 years old that are mainly composed of German tend to choose their dwellings in suburbs. There are 82 districts with high ratio for old people more than 20 percent and 64 districts out of them are located in suburbs outside $3 \mathrm{~km}$ form the center. The ratio for old people reaches to 15.5 percent within $3 \mathrm{~km}$ from the center, which is less than that of suburbs (19.3 percent). They live especially within 4 or $5 \mathrm{~km}$ from the center to its northeast and to southwest where there are many detached and semidetached housings.

\section{REGIONAL PATTERN OF RESIDENTIAL RENEWAL}

\section{Social housing units}

Social housing units are constructed though the financially supporte by public sector, based on the First and Second Housing Construction Acts in addition to the Housing Act in 1946 
(das Wohnungsgesetz von 1946). Up to the early 1970s, the annual average for housing completions is 5,611 units in Nuremberg between 1950 and 1969, out of which 57.5 percent was social housing units. As the total number of housing construction decreased in the first half of the 1970s, so did the budgets for construction of social housing units. The annual average for the housing completions reaches to 2,632 units between 1970 and 2000, out of which 26.6 percent was social housing units.

The social housing units contribute to urban renewal in two ways. The first is the increase in the construction of modernized dwellings in and around the urban area. Especially in up to the early 1970s, the social housing units were provided for the increasing population that moved into the city during the economic growth. Many of them were furnished with required residential facilities at that time and constructed in and around the urban area.

The second is the contribution for the maintenance or improvement of old buildings. Since social housing units are financially supported by public sector for modernization of residential facilities such as heating units and for maintenance of façade, they tend to keep good condition or catch up with the standard, at least, in quality. The old social housing units are maintained or improved in the framework of residential modernization program or renewal program based on the Second Housing Construction Acts. The statistical districts of high ratio for them are located in the suburbs beyond $3 \mathrm{~km}$ from the center to its northeast and south in 2000 . Within $3 \mathrm{~km}$ from the center, the districts with high ratio are concentrated in northwest.

\section{Urban renewal projects}

Both owners and city authorities have renovated more old buildings in the urban central area than before since the 1970s. Figure 1 illustrates the spatial distribution of the urban renewal project's areas in Nuremberg. 12 renewal projects have planned and took into effect since 1973 and 7 renewal projects out of them have already finished or will be finished until the end of 2003. 11 projects are located in the old urban area developed up to the early 20th century within $2 \mathrm{~km}$ from the city center. The total area of them reaches to 226.3 hectare and those total budgets amount to 173.9 million Mark in 2001.

In the scheme of old urban renewal projects in the 1970s, many old buildings were completely destroyed and reconstructed, but a small number of dwellings were renovated for the sake of modernization of residential facilities. These measures led not only to dramatic changes in demographic structure, but also to the slow but steady increase in the number of the new flats with large floor space and with modern residential functions for the long period of time, into which Germans and foreigners have moved. The new scheme of renewal projects after the 1980s paid much more attention to the re-use of existing housing units and social resources. The effects on improving standards of flats were not small, but not enough, when we compare them with those of the old projects in the 1970s. This means the existence of old flats with small floor space and substandard residential facilities, whose rents tend to be cheaper than the modernized flats. As a result, the ratio for foreigners, single households and young couple with their child or children increase in number for a long period of time (Ito, 2003). 
Figure 1: Areas of urban renewal projects in Nürnberg, 1998

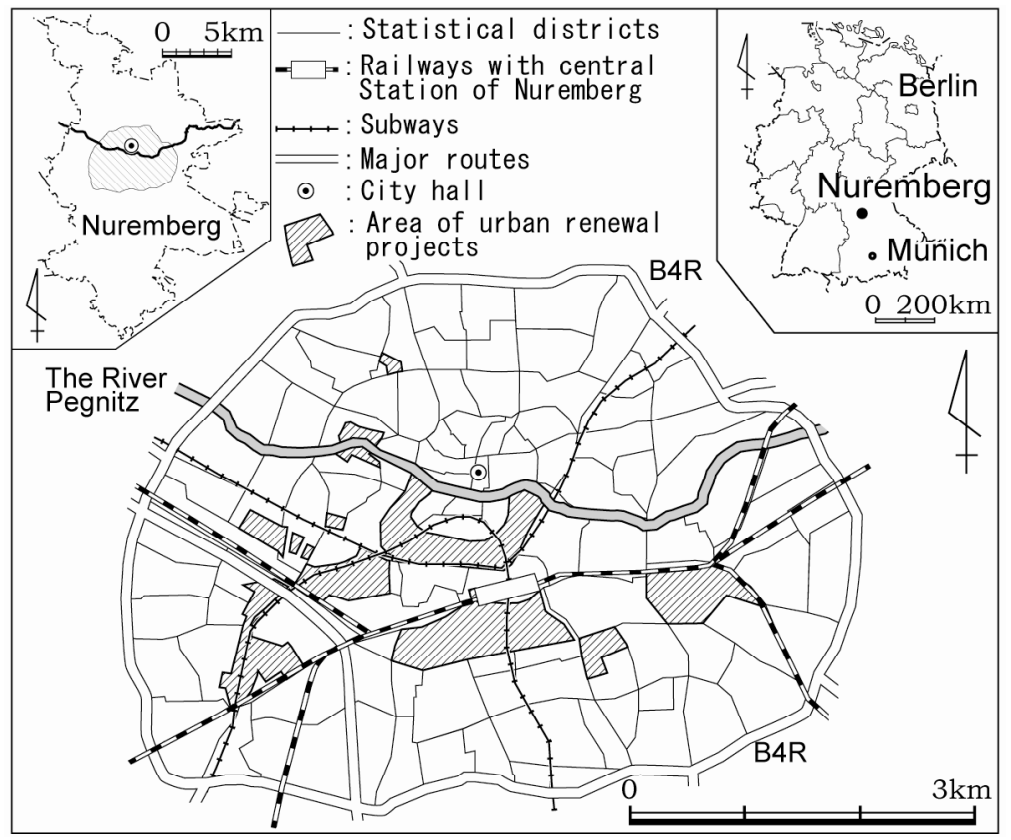

Source: Übersichtplan der Stadterneuerungsgebite, Stadt- planungsamt Nürmberg, 1998

\section{The regional pattern of construction in Nürnberg}

Figure 2 illustrates the density of housing units per hectare in 1989 and the renewal rate that means the number of housing completions between 1989 and 1998 per 100 housing units in 1989. According to the two maps, I find three important viewpoints on regional pattern of build environment. Firstly, Figure 2-1 illustrates a clear contrast of dwelling density between the area within $3 \mathrm{~km}$ from the center and the other area in suburbs. The housing units are concentrated within $3 \mathrm{~km}$ from the center. The density of housing units per hectare reaches to 55.4 units within $3 \mathrm{~km}$ from the center, whose number is by 7.3 times bigger than that in the suburbs (7.6 units). Because many parts of land had already been developed in the 19th and the early 20th century in the area within $3 \mathrm{~km}$ from the urban center, lots of old dwellings should be reconstructed or renovate for modernization of residential facilities and for getting larger floor space.

Then, the districts with high renewal rate are spatially distributed both in the urban area within $3 \mathrm{~km}$ from the center and in southern suburbs far beyond the center. According to Figure 2-2, the districts belonging to the highest renewal rate over 10 units are located not only in the southern suburbs over $3 \mathrm{~km}$ form the center, but also in the north part of the old urban area within $3 \mathrm{~km}$ from the center. In the former, new middle or large apartment buildings have been constructed in the residential estate that had developed mainly in the 1960s and 1970s, so that the renewal rate became higher than before. In the latter, lots of old hou- 
sing units were reconstructed into a large dwellings with modernized housing facilities, especially in northern part of the city hall and southeast part that locates very close to central station. In the southeast part, the renewal rate in the urban renewal project's area is much higher than that in the area without projects. This fact suggests that the projects caused to increase in the renewal in the residential areas.

Figure 2: Regional pattern of construction in Nürnberg, 1989-98

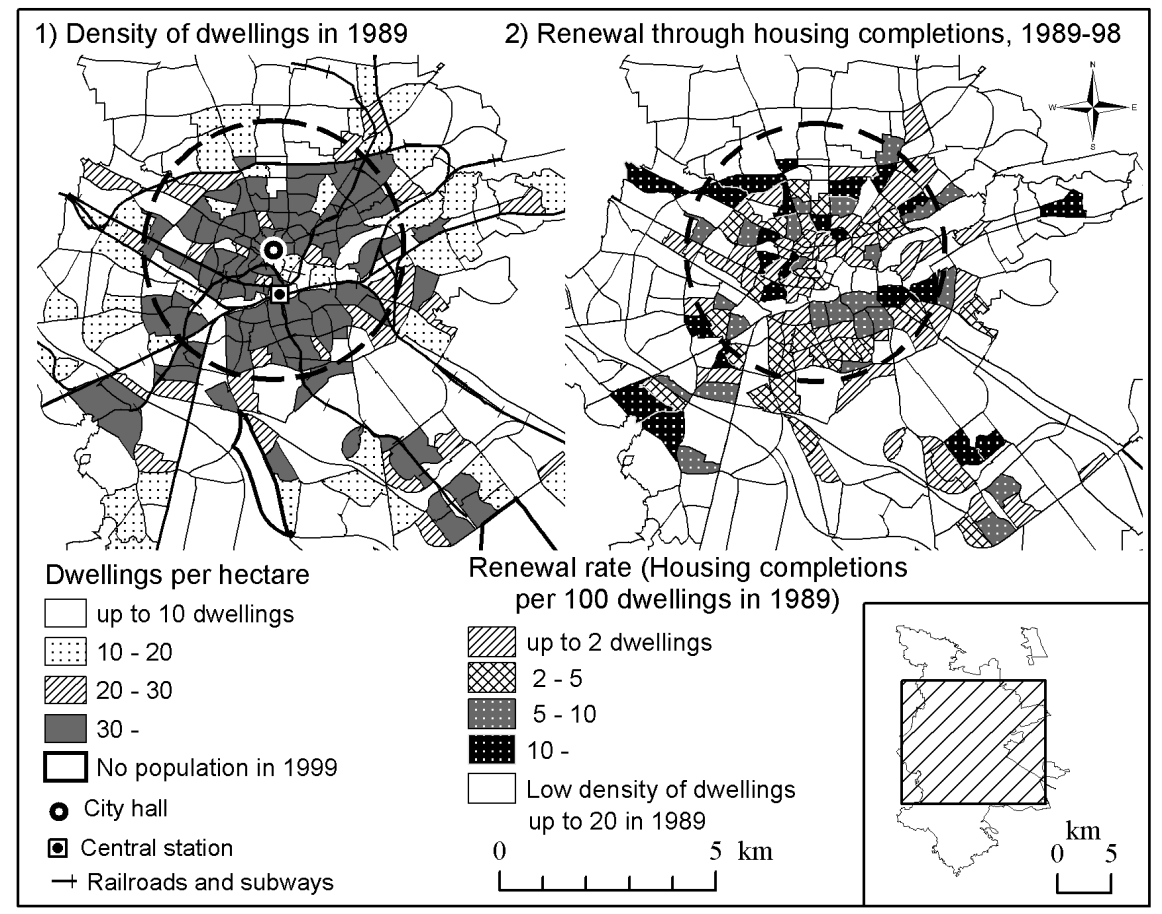

Source: Statistisches Datensatz der Amt für Stadtforshung und statistik der Stadt Nürnberg

Finally, I point out the changes in the social structure and residential quality in the districts with high renewal rate within $3 \mathrm{~km}$ from the center. In 13 districts classified into highest renewal rate over 10 units, the ratio for foreigners ( 21.1 percent) is less than that in 44 districts with lowest rate up to 2 units (27.4 percent). Many reconstructions and renovations in the 1980s and 1990s led to the increase in the number of large and high quality dwellings, into which many German households and households of medium or high socioeconomic status moved. By contrast, due to a small number of reconstructions and renovations, many dwellings remain to be small size and to be middle or low quality dwellings with a low or medium rent, into which people with low incomes move such as foreigners. The ratio for small size housing units up to 60 Quadra meter reaches to 46.7 percent in the districts with lowest rate, while that in the districts with highest rate reaches only to 38.4 percent. Further-more, the ratio for social housing units (7.1 percent) in the districts with highest rate is higher than that 
(4.7 percent) in the districts with lowest rate. It suggests from this that not only the private investment in the housing construction but also social housing units contributed to the formation of the well-cared-for area.

\section{CONCLUSIONS}

The purpose of this study is to investigate regional pattern of renewal in urban residential areas in Germany since the 1970s. Figure 3 is achieved by comparing the results of analysis on the regional patterns of physical and social structure. The "well-cared-for area" is located in east sector within $3 \mathrm{~km}$ from the center to the north and the south. The number of constructions that include social housing units is more than in the other. In this type of area, the owners maintain their dwellings in a satisfactory physical condition, into which residents in the middle or upper classes, and German young or middle-aged people move. The city authority has planned public interventions for improvement, namely urban renewal projects in the distressed residential area and the social housing units have constantly constructed since the 1970s. The combination of public intervention and private investment in construction has led to the formation of well-cared-for area.

Figure 3: Regional pettern of renewal in residenta areas in Germany

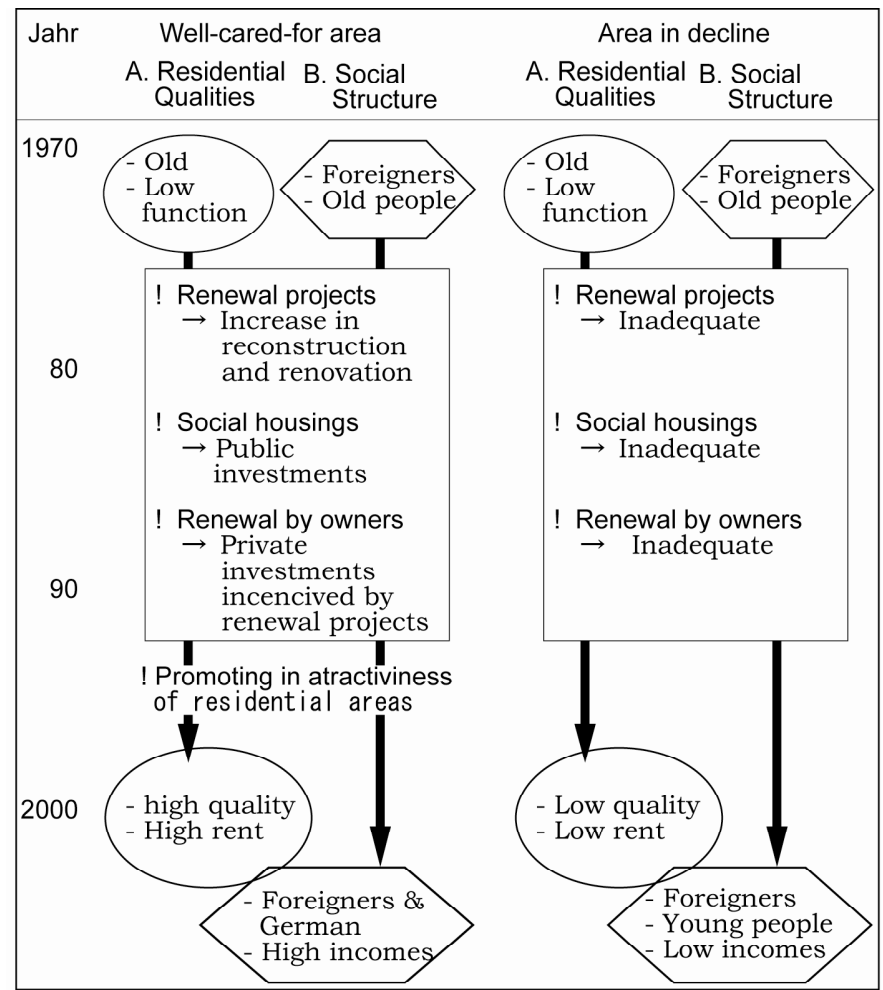


The second type is an "area in decline", which is found in the southwest sector within $3 \mathrm{~km}$ from the center to the west and south. This area corresponds to the urban residential area developed in and shortly after the period of industrialization and is spatially connected with the industrial area. In this area, there are low rent dwellings of middle or low quality, in which many residents with low incomes such as foreigners live. The combination of public intervention and private investment in construction is less than that of former.

This thesis reveals that renovation and reconstruction by private owners as well as urban renewal projects play a vital role in renewal in urban residential areas. This means that it is essential for the sustainable renewal not only to improve the residential facilities by public projects but also to promote the change by private sector in residential area. Although this study investigated renewal and its characteristics based on a case study in Nuremberg, a precise comparison of several cities in Germany remains to be done.

\section{Acknowledgments}

I would like to express my deepest gratitude to Prof. Dr. J. Maier at the University of Bayreuth, to Prof. Dr. G. Heinritz and Dr. W. Kühn at the University of Munich for their support and for the fertilizing environment that each of them has created. Some part of research in 2002 was partly financially supported by the Grants-in-Aid for Scientific Research in 2002 (Grant-in-Aid for JSPS Fellows, No.6000 and Main researcher: ITO Tetsuya).

\section{References}

Amt für Stadtforschung und Statistik, 1996: Nürnberg in Zahlen. Nürnberg, Presse- und Informationsamt.

Amt für Stadtforschung und Statistik, 1999: Statistitsches Jahrbuch der Stadt Nürnberg 1985. Nürnberg, Stadt Nürnbergs Hausdruckerei.

Carmon, N., 1999: Three generation of urban renewal policies - analysis and policy implications. Geoforum, 30, 145-58.

Daase, M., 1995: Prozesse der Stadterneuerung in innenstadtnahen Wohngebieten am Beispiel Hamburg - Ottensen. Mitteilungen der Geographischen Gesellschaft in Hamburg, $85,1-141$.

Eltages, M., und Walter, K., 2001: Einführung-Städtebauförderung: historisch gewachsen und zukunftsfähig, Informationen zur Raumentwicklung (Bundesamt für Bauwesen und Raumordung), Heft 9/10, 1-10.

Hatz, W., 2001: Altstadtsanierung in Augusburg-Investionen, Auswirkungen auf die Bevölkerung, Perspektiven. Angewandete Sozialgeographie, 41, 119-288.

Heineberg, H., 1988: Die Stadt im westlichen Deutschland-Aspekte innerstädtischer Struktur und Funktionsveränderung in der Nachkriegszeit. Geographische Rundschau, 40(1), 20-9.

Heineberg, H., 2001: Grundriß Allgemeine Geographie: Stadtgeographie (2. aktualisirte Auflage). Paderborn, Schöningh. 
Ito, T., 2003: The physical and social changes in the urban residential areas redeveloped by urban renewal projects in Germany-A case study of Nuremberg since the 1970s. Annals of the Japan Association of Economic Geographers, 49, 197-217.

Killisch, W., Moch, K., 1976: Bevölkerungs- und sozialgeographische Untersuchung als Grundlage der Sanierungs- und Sozialplanung-Ein Beitrag zur angewandten Geographie. Erdkunde, 30, 253-65.

Lichtenberger, E., 1990: Stadtverfall und Stadterneuerung. Wien, Österreichische Akademie der Wissenschaften.

Lochner, I., 1987: Wirkungsanalyse von Stadterneuerungen: dargestellt am Beispiel zweiter Altstadtquartiere in Ingorstadt. Arbeitsmaterialien zur Raumordnung und Raumplanung am Lehrstuhl Wirtschaftsgeographie und Regionalplanung der Universität Bayreuth, Heft 54, 1-169.

Maier, J., Troeger-Weiß, G., 1990: Suburbanisierung im mittelfränkischen Verdichtungsraum-Entwicklungen, Strukturen sowie Konsequenzen für die kommunale Wirtschaftspolitik und Landesentwicklungspolitik. Arbeitsmaterial der Akademie für Raumforschung und Landesplanung, EV 173, 88-134.

Müller, B., 1985: Das Bleiweißviertel in Nürnberg: Veränderung der Bevölkerungsstruktur während der Sanierung. Mitteilungen der Fränkischen Geographischen Gesellschaft, 29/30, 373-401.

Wiessner, R., 1988: Probleme der Stadterneuerung und jüngerer Wohnungsmodernisierung in Altbauquartieren aus sozialgeographisher Sicht - Mit Beispielen aus Nürnberg. Geographische Rundschau, 40(11), 18-25. 